IRA-International Journal of Applied Sciences

ISSN 2455-4499; Vol.12, Issue o3 (September 2018)

Pg. no. 15-29.

Institute of Research Advances

https://research-advances.org/index.php/IRAJAS

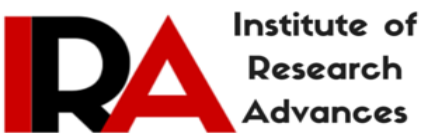

\title{
Comparative Study of the Effects of Different Fractions of Ficus Exasperata Vahl on Rat Hepatic Mitochondrial Membrane Permeability Transition Pore
}

\author{
Adeola F. Ehigie ${ }^{1}$, Olajumoke O. Nwaechefu ${ }^{2}$, Godswill N. Anyasor ${ }^{3}$, Faith S. Oyelere ${ }^{1}$, \\ Tosin S. Sangodipe ${ }^{1}$, and Leonard O. Ehigie ${ }^{1 \#}$
}

${ }^{1}$ Department of Biochemistry, College of Health Sciences, Ladoke Akintola University of Technology, Ogbomoso, Nigeria.

${ }^{2}$ Department of Biochemistry, Lead City University, Ibadan, Nigeria.

${ }^{3}$ Department of Biochemistry, Benjamin S. Carson (Snr) School of Medicine, College of Health and Medical Sciences, Babcock University, Ogun State, Nigeria.

\#corresponding author.

Type of Review: Peer Reviewed.

DOl: http://dx.doi.org/10.21013/jas.v12.n3.p1

\section{How to cite this paper:}

Ehigie, A.F., Nwaechefu, O.O., Anyasor, G.N., Oyelere, F.S., Sangodipe, T.S., Ehigie, L.O. (2018).

Comparative Study of the Effects of Different Fractions of Ficus Exasperata Vahl on Rat Hepatic Mitochondrial Membrane Permeability Transition Pore. IRA International Journal of Applied Sciences (ISSN 2455-4499), 12(3), 15-29. doi:http://dx.doi.org/10.21013/jas.v12.n3.p1

(C) Institute of Research Advances.

\section{(cc) EY-NC}

This work is licensed under a Creative Commons Attribution-Non Commercial 4.0 International License subject to proper citation to the publication source of the work.

Disclaimer: The scholarly papers as reviewed and published by the Institute of Research Advances (IRA) are the views and opinions of their respective authors and are not the views or opinions of the IRA. The IRA disclaims of any harm or loss caused due to the published content to any party.

Institute of Research Advances is an institutional publisher member of Publishers International Linking Association Inc. (PILA-CrossRef), USA. The institute is an institutional signatory to the Budapest Open Access Initiative, Hungary advocating the open access of scientific and scholarly knowledge. The Institute is a registered content provider under Open Access Initiative Protocol for Metadata Harvesting (OAI-PMH).

The journal is indexed \& included in CAS Source Index of Chemical Abstracts Service of American Chemical Society (USA), Index Copernicus (IC Value 85.27), WorldCat Discovery Service (USA), CrossRef Metadata Search (USA), WorldCat (USA), OCLC (USA), Open J-Gate (India), EZB (Germany) Scilit (Switzerland), Airiti (China), Bielefeld Academic Search Engine (BASE) of Bielefeld University, Germany, PKP Index of Simon Fraser University, Canada. 


\begin{abstract}
A number of phytochemicals have been established as potent inducers of the mitochondrial membrane permeability transition (MMPT) pore, a transient structure formed in the inner mitochondrial membrane (IMM). There is however no information on the effect of Ficus exasperata (F. exasperata) a popular medicinal plant, on this pore, necessitating this investigation. The in vitro effects of varying concentrations $(200,400,600,800$ and $1000 \mu \mathrm{g} / \mathrm{ml})$ of the methanol, $n$-hexane and ethylacetate fractions of leaf and stem of F. exasperata on MMPT pore opening in experimental rat liver were assessed. Opening of MMPT pore was spectrophotometrically assayed under succinate-energized condition using a modified method of Lapidus and Sokolove, 1993 ${ }^{[34]}$. The results obtained for the Stem Methanol Fraction (SMF) and Leaf Methanol Fraction $(L M F)$ show significant $(P<0.05)$ increases in the extents to which MMPT pore opening was induced at all concentrations compared with the control group, with the highest induction observed at $400 \mu \mathrm{g} / \mathrm{ml}$ and the least seen at $1000 \mu \mathrm{g} / \mathrm{ml}$. The inductive effects of Leaf n-hexane Fraction (LHF) and Stem n-hexane Fraction $(S H F)$ increased as concentration increased such that the highest induction observed in LHF and SHF were 2.80 and 2.28 fold increases respectively. Leaf Ethylacetate Fraction (LEF) and Stem Ethylacetate Fraction (SEF) of F. exasperata also show a concentration dependent effect such that the inductive effect decreased as concentration increased i.e. at $200 \mu \mathrm{g} / \mathrm{ml}$ of $\mathrm{LEF}$ and $S E F, 3.97$ and 4.25-fold increases were achieved respectively while the least folds in induction were observed at $1000 \mu \mathrm{g} / \mathrm{ml}$ for both at 2.0 -fold and 1.97 -fold respectively. Taken together, all tested fractions of $F$. exasperata have significant $P<0.05$ inductive effect on the MMPT pore opening at all tested concentrations, the most potent fraction being the SEF. We thus conclude that F. exasperata is an effective inducer of the MMPT pore, albeit, different fractions derived from different parts vary in their potency. Also, F. exasperata could find a great use in the treatment of ailments dependent on the induction of the mitochondrial membrane permeability transition pore opening.
\end{abstract}

Key Words: MMPT Pore, Ficus exasperata, Methanol, N-Hexane and Ethylacetate

\title{
INTRODUCTION
}

Mitochondria are essential for human existence, and thus are involved in numerous cell processes that rely on energy sustenance such as cell growth, cell messaging, aging and replication, for this same reason, mitochondria are known to be associated with several diseases of energy demanding organs and tissues of the body including the heart, brain and skeletal muscle ${ }^{[1]}$. Thus, mitochondrial membrane potential (or proton motive force) is the central bio-energetic parameter that controls respiratory rate, ATP synthesis and the generation of reactive oxygen species, and its self-controlled by electron transport and proton leaks ${ }^{[2]}$. Opening of the mitochondrial membrane permeability transition (MMPT) pore causes the cell to show the characteristics of apoptosis by promoting the release of apoptotic proteins ${ }^{[3]}$.

The term "mitochondrial permeability transition" refers to a sudden and irreversible increase in the permeability of the inner mitochondrial membrane (IMM) to small solutes, leading to mitochondrial trans-membrane potential $(\triangle \Psi \mathrm{m})$ dissipation, ATP synthesis arrest, unregulated entry of water into the mitochondrial matrix, and osmotic breakdown of the organelle ${ }^{[4]}$.

The MMPT Pore may function as a self-amplifying "switch" that, once activated, irreversibly commits the cell to apoptosis ${ }^{[5,6,7]}$. If cytosolic $\mathrm{Ca}^{2+}$ concentrations become too high, as following excessive neuronal firing or severe energy shortage, the subsequent mitochondrial $\mathrm{Ca}^{2+}$ overload will initiate the opening of a nonspecific pore in the inner membrane ${ }^{[8]}$. This $\mathrm{Ca}^{2+}$ dependent formation of the MMPT Pore represents an abrupt increase of permeability to solutes normally impermeable to the inner membrane $(\mathrm{Mw}<1500 \mathrm{Da})$, causing osmotic swelling and rupture of the outer membrane, with concomitant loss of mitochondrial proteins ${ }^{[9]}$.

Opening of the mitochondrial membrane permeability transition (MMPT) pore causes the cell to show the characteristics of apoptosis by promoting the release of apoptotic proteins ${ }^{[10]}$. Apoptosis occurs primarily via two well-recognized pathways in cells $\mathrm{s}^{[11,12]}$; the extrinsic, or death receptor-mediated and the intrinsic, or mitochondrial-mediated, pathways ${ }^{[13]}$. The intrinsic apoptotic pathway depends notably on the permeabilization of mitochondrial membranes, with associated release of apoptogenic mitochondrial proteins, resulting in activation of caspase-9 and downstream cleavage of caspases 3,6 , or $7^{[14]}$ and is characterized by alteration in mitochondrial polarization and release of such mitochondrial proteins as cytochrome c, which in turn can trigger caspase activation and ultimately execution of apoptosis ${ }^{[15]}$. 
Ficus exasperata is a terrestrial plant that grows $20 \mathrm{~m}$ high with smooth grey bark and very rough leaves on both surfaces; viscid non-milky sap; and coppice shoots with lobed leaves and inhabits the evergreen and optional rainforest of West Africa. It belongs to the family Moraceae with over 800 species occurring in the warmer parts of the world ${ }^{[16]}$. F. exasperata is commonly known as sand paper tree ("Ewe ipin" in Yoruba) and is widely spread in West Africa ${ }^{[17]}$. The plant is well known in Africa for its utilization in the treatment of different illnesses.

The leaves of Ficus exasperata are distichous, alternate, ovate to elliptic, subcoriaceous to coriaceous, apex shortly acuminate, base acute to obtuse, upper surface scabrous having a harsh surface, making them look like sand paper and therefore the name, sandpaper tree. The plant bears figs, which usually appear in pairs in the leaf axils. Figs are discovered either as lone or in sets in the leaf axils and rarely on matured wood. The bark of the plant is smooth grayish cream with brown streets and it radiates sticky sap. ${ }^{[18,19,20]}$

Available reports indicate that leaves of $F$. exasperata exhibit antiulcer, hypotensive, hypoglycemic, hypolipidemic, anti-inflammatory, anxiolytic, oxytocin inhibiting, anticonvulsant, antinociceptive, antipyretic, anti-microbial, anti candidal, insecticidal and pesticidal activities ${ }^{[21,22,23,24,2,26,27,28]}$. The leaves, stem bark and roots are reported to contain certain phytochemicals such as steroids, flavonoids, phlobatannins, tannins and saponins ${ }^{[2,30]}$ alkaloids, cardiac glycosides ${ }^{[31]}$ and a new unnamed acylglucosylstero ${ }^{[32]}$; unusual fatty acid from the leaves. Reports on the modulatory effects of this all important medicinal plant, $F$. exasperata on the MMPT pore opening are however nonexistent, birthing our curiosity in this present study wherein we elucidated the modulatory effect of $F$. exasperata on rat hepatic mitochondrial membrane permeability transition pore.

\section{MATERIALS}

\section{Plant}

Fresh leaves and stem of Ficus exasperata valh were obtained from the premises of the College of Medicine, LAUTECH Ogbomoso, Oyo state. The collected leaves were identified and authenticated by Prof. A.T.J. Ogunkunle, an Angiosperm Determinist of the Department of Pure and Applied Biology, Botany unit, Faculty of Pure and Applied Science, Ladoke Akintola University of Technology, Ogbomoso. The plant herbarium number is LHO 511.

\section{Preparation of Ficus exasperata Fractions}

The leaves and stems of Ficus exasperata were separated, rinsed with clean water, and air-dried separately in a wellventilated room for about two weeks. Two hundred and fifty grams $(250 \mathrm{~g})$ of leaves and about one hundred grams $(100 \mathrm{~g})$ of stem were each pulverized using a manual blender and subsequently soaked in $1000 \mathrm{ml}$ each of the selected solvents to obtain the Leaf methanol fraction (LMF), Stem methanol fractions (SMF), Leaf n-hexane fraction (LHF), Stem n-hexane fraction (SHF), Leaf ethyl acetate Fraction (LEF) and Stem ethylacetate fraction (SEF). After 24hours of soaking at room temperature with occasional agitation, the macerates were filtered and concentrated to dryness in a Rotary evaporator at $65^{\circ} \mathrm{C}$ and the different fractions were preserved at low temperature $\left(4^{\circ} \mathrm{C}\right)$ for experimental use. The yield was about $1.83 \%(\mathrm{SEF}), 2.772 \%(\mathrm{LMF})$ and $2.678 \%$ (SMF), 0.96\% (SHF), $1.83 \%$ (LHF) and $2.72 \%$ yield of (LEF) of the raw material.

\section{Experimental Animals}

Twenty healthy Wistar strain albino male rats (between $120 \mathrm{~g}-150 \mathrm{~g}$ ) were purchased from commercial Breeders in Ogbomoso and kept at the Faculty of Basic Medical Sciences' Animal House, LAUTECH, Ogbomoso, Nigeria, under light-controlled conditions (12h-light/12h-dark cycle) and in well-ventilated plastic cages. The animals received formulated feeds and water ad libitum, were allowed to acclimatize over a period of two weeks and cared for in accordance with good laboratory animal care practice prescribed by the Faculty of Basic Medical Sciences' Animal Care and Use Committee.

\section{Chemicals and Reagents}

Sodium Carbonate $\left(\mathrm{Na}_{2} \mathrm{CO}_{3}\right)$, Sodium Hydroxide $(\mathrm{NaOH})$, Sodium-Potassium Tartarate $\left(\mathrm{Na}-\mathrm{K}-\mathrm{C}_{4} \mathrm{O}_{6}\right)$, Hydrated Copper Sulphate $\left(\mathrm{CuSO}_{4} .5 \mathrm{H}_{2} \mathrm{O}\right)$, Calcium Chloride $\left(\mathrm{CaCl}_{2}\right)$, Potassium Hydroxide $(\mathrm{KOH})$, Methanol were Products of BDH Poole, UK Ltd. and Co., while Folin Ciocalteau Reagent, BSA, Mannitol, Sucrose, HEPES [4-(2- 
Hydroxyethyl) piperazine-1-ethanesulfonic acid], EGTA, Spermine, Rotenone, and Sodium Succinate (hexahydrate) were Products of Sigma-Aldrich Co, USA. All chemicals were of analytical grade.

\section{METHODS}

\section{Mitochondrial Isolation}

The low ionic strength mitochondrion was isolated using a method described by Johnson and Lardy, $1967{ }^{[33]}$. The experimental animals were fasted overnight then sacrificed by "cervical dislocation" and quickly dissected. The liver was rapidly excised, trimmed to remove excess tissue and washed in homogenizing buffer (210 $\mathrm{mM}$ Mannitol, 70 $\mathrm{mM}$ Sucrose, $5 \mathrm{mM}$ HEPES, and $1 \mathrm{mM}$ EGTA, $\mathrm{pH}$ 7.4) Thereafter, the liver was weighed, chopped and suspended in the same buffer to make a $10 \%$ suspension of tissue in buffer. Immediately the liver was homogenized on ice using a glass Bosch PSB 570-2 Homogenizer. The homogenate was sedimented twice in a Shuke (TGL-22) at 2500rpm for 5 minutes to remove the nuclear fractions and cellular debris, supernatant obtained was centrifuged at 13000rpm for 10 minutes and mitochondria fraction obtained was washed three times in washing buffer (210 $\mathrm{mM}$ Mannitol,70mM Sucrose, 5mM HEPES-KOH and 0.5\% BSA, pH 7.4 at 12000rpm for 10 minutes. The mitochondrial pellets were suspended in swelling buffer $(210 \mathrm{mM}$ Mannitol, $70 \mathrm{mM}$ Sucrose, and $5 \mathrm{mM}$ HEPES$\mathrm{KOH}, \mathrm{pH}$ 7.4) and immediately dispensed in $1 \mathrm{ml}$ Eppendorf tubes as the isolate which was used within 3 hours of isolation.

\section{Mitochondrial Swelling Assays}

Permeability transition is detected in isolated mitochondria by the change in the diffraction/absorption of light (measured at $540 \mathrm{~nm}$ ) that results from matrix swelling ${ }^{[8]}$. Thus, changes in the volume of isolated liver mitochondria were measured quantitatively at $540 \mathrm{~nm}$ in an SM32A spectrophotometer based on the procedure of Lapidus and Sokolove, $1993^{[34]}$. Mitochondria $(0.4 \mathrm{mg}$ of protein/ml) were pre-incubated in a $1 \mathrm{~cm}$ light path glass cuvette in the presence of $80 \mu \mathrm{M}$ rotenone in swelling buffer containing $210 \mathrm{mM}$ Mannitol, $70 \mathrm{mM}$ Sucrose, $5 \mathrm{mM}$ HEPES- KOH, pH 7.4 for about $3 \mathrm{~min}$ at $32^{\circ} \mathrm{C}$ prior to the addition of $300 \mu \mathrm{M} \mathrm{CaCl}_{2}$ (triggering agent). Thirty seconds later, $5 \mathrm{mM}$ sodium succinate was added and mitochondrial permeability was quantified as changes in absorbance at $540 \mathrm{~nm} .4 \mathrm{mM}$ spermine was added immediately after the addition of rotenone and just before the addition of mitochondria for the determination of spermine inhibition while the addition of $300 \mu \mathrm{M} \mathrm{CaCl} \mathrm{Cl}_{2}$ was omitted in assays without triggering agent. For determination of the extents of opening of mitochondrial membrane permeability transition pore induced by the leaf and stem fractions of $F$. exasperate, varying concentrations $(200,400,600,800$ and $1000 \mu \mathrm{g} / \mathrm{ml})$ of each fraction were immediately introduced after the addition of rotenone and just before the addition of mitochondria (pre-incubated with mitochondria). Absorbance readings were monitored continuously for 12 minutes based on the procedure of Lapidus and Sokolove, $1993^{[34]}$. The 12-minute cut-off was found to be optimal in obtaining a wide range of activities of the triggering agent and fractions on MMPT pore opening. Readings up to the 12th minute gave sufficient absorbance reading without loss of integrity of the mitochondrial samples ${ }^{[35]}$. Protein concentration was estimated according to the method of Lowry et al., $1951^{[36]}$ using bovine serum albumin (BSA) as the standard.

\section{Statistical Analysis}

Results were analyzed using student's $t$ test. All data were expressed as Mean \pm Standard Error of Mean. All results obtained for the extracts as well as that for the Triggering agent (Calcium) are significant at $\mathrm{P}<0.05$. Graph Pad Prism 5 and Microsoft Excel 2007 were used for the analyses.

\section{RESULTS}

In figure 1, results obtained showed that large amplitude swelling was triggered by $\mathrm{Ca}^{2+}$ (triggering agent) in normal healthy Wistar male rat liver mitochondria. This large amplitude swelling was observed when $\mathrm{Ca}^{2+}$ was added after a 3-minute incubation with mitochondria. A 9.82-fold increase in the extent of opening of the $\mathrm{Ca}^{2+}$-treated mitochondrial membrane permeability pore, which is a significant induction at $(\mathrm{P}<0.05)$ was achieved. This result is in accordance with the finding that treatment of isolated mitochondrial with $\mathrm{Ca}^{2+}$ permeabilizes the inner membrane of mitochondria, releasing small solutes such as glutathione and $\mathrm{Ca}^{2+[37]}$. The induction by calcium was reversed by an $80.42 \%$ inhibition in the presence of spermine, a standard inhibitor of the MMPT pore. 


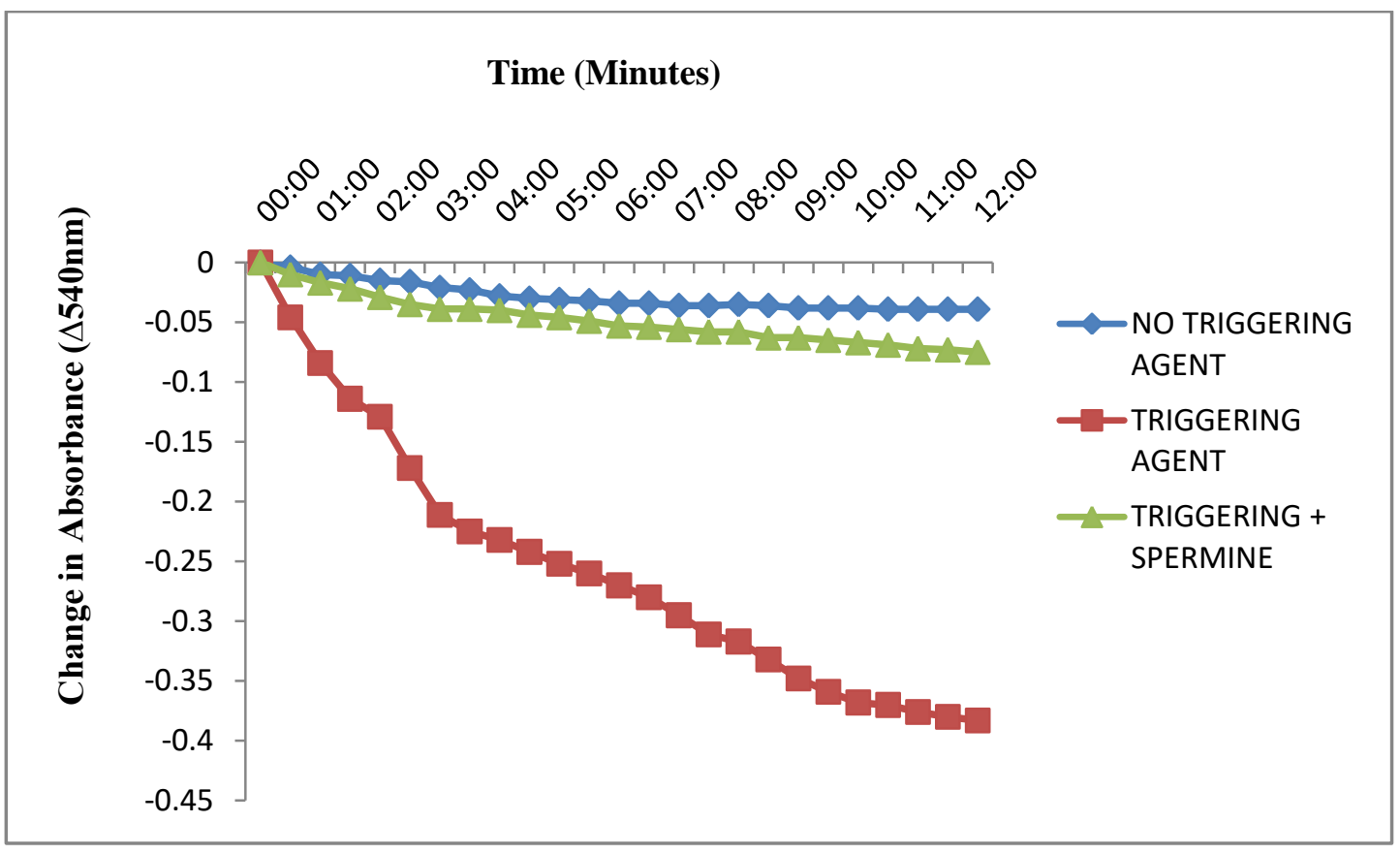

Figure 1: In-vitro Induction and inhibition of $\mathrm{Ca}^{2+}$-induced opening of MMPT pore in Normal Wistar strain rat liver.

Figure 1 above shows a 9.82-fold increase in induction in the group of mitochondria treated with the standard inducer (300 $\mu \mathrm{M} \mathrm{CaCl}{ }_{2}$ \{Trigering Agent\}) when compared with the untreated control group (No Triggering Agent). This observed induction is being reversed by spermine, a standard inhibitor of the MMPT pore by $80.42 \%$.

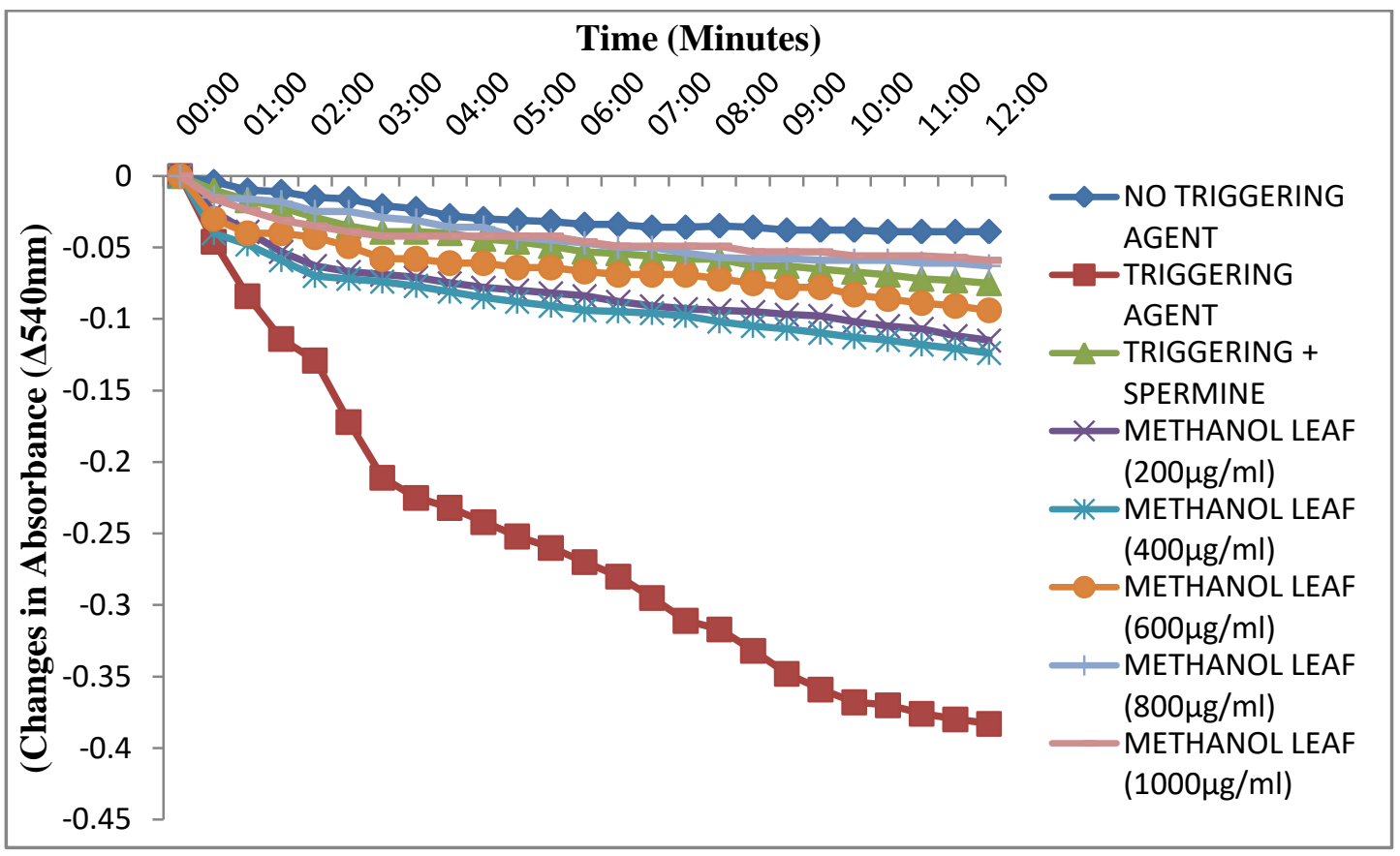

Figure 2: Showing the effect of Leaf Methanol Fraction (LMF) of Ficus exasperata at varied concentrations on mitochondrial Permeability Transition Pore. 
Here, the in vitro induction of rat liver MMPT pore opening by varying concentrations of leaf methanol fraction $(L M F)$ of F. exasperate are shown. Varying concentrations of LMF induced MMPT pore opening in a somewhat concentration-dependent manner, with the inductive effect decreasing with increasing concentrations of fraction such that at $200 \mu \mathrm{g} / \mathrm{ml}$, change in absorbance $\left(\Delta_{540 \mathrm{~mm}}\right)$ was -0.115 translating to 2.94 -fold increase, at $400 \mu \mathrm{g} / \mathrm{ml}$, $\Delta_{540 \mathrm{~nm}}$ was -0.124 being a 3.17-fold increase and at $600 \mu \mathrm{g} / \mathrm{ml}$, $4540 \mathrm{~nm}$ was -0.094 translating to a 2.41 -fold increase. Furthermore, a 1.61 fold increase was observed at $800 \mu \mathrm{g} / \mathrm{ml}\left(\Delta_{540 \mathrm{~mm}}=-0.063\right)$ while at $1000 \mu \mathrm{g} / \mathrm{ml}, \Delta_{540 \mathrm{~nm}}$ is -0.059 translating to 1.51-fold increase. Leaf Methanol Fraction of F. exasperata causes significant $(P<0.05)$ induction at all concentration with the highest induction observed at $400 \mu \mathrm{g} / \mathrm{ml}$.

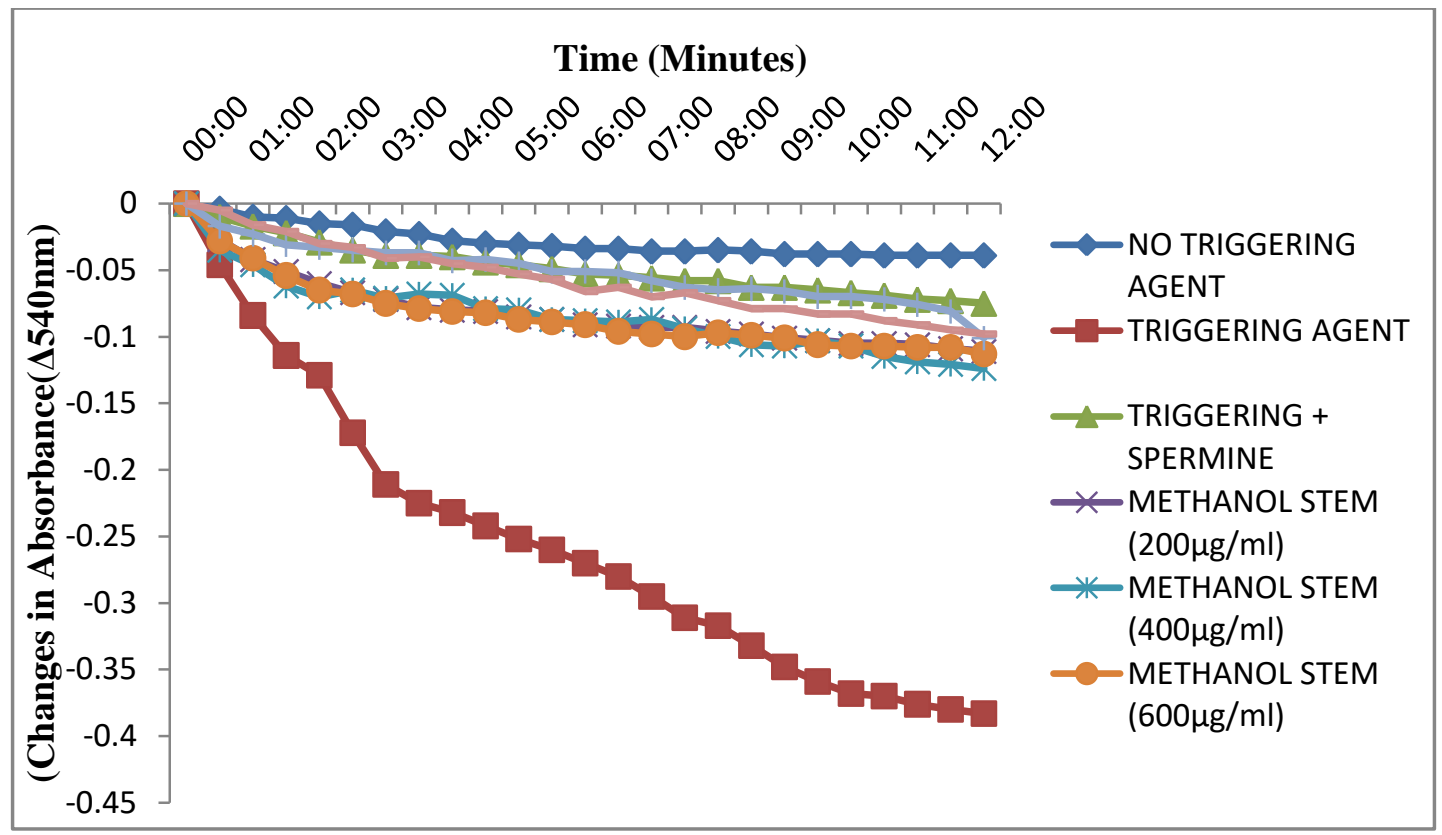

Figure 3: Showing the effect of Stem Methanol Fraction (SMF) of Ficus exasperata at varied concentrations on mitochondrial Permeability Transition Pore.

Figure 3 shows the in vitro induction of rat liver MMPTP opening by varying concentrations of Stem methanol fraction of Ficus exasperata. In the same vein with LMF, Varying concentrations of SMF induced MMPTP opening in a somewhat concentration-dependent manner, with the induction increasing with increasing concentrations of fraction. A 2.84-fold increase was observed at $200 \mu \mathrm{g} / \mathrm{ml}\left(\Delta_{540 \mathrm{~nm}}=-0.111\right)$, at $400 \mu \mathrm{g} / \mathrm{ml}, \Delta_{540 \mathrm{~nm}}=-0.124(3.17-$ fold increase), 2.89-fold was observed at $600 \mu \mathrm{g} / \mathrm{ml}$ with a $\Delta_{540 \mathrm{~nm}}$ of -0.113 , at $800 \mu \mathrm{g} / \mathrm{ml}\left(\Delta_{540 \mathrm{~nm}}=-0.101\right)$ which translates to 2.58-fold increase and a 2.51-fold increase was observed at $1000 \mu \mathrm{g} / \mathrm{ml}$ with $\Delta_{540 \mathrm{~nm}}=-0.098$. At all concentrations, Stem Methanol fractions of Ficus exasperata trigger significant $(P<0.05)$ openings of the Mitochondria Membrane Permeability Transition Pore. 


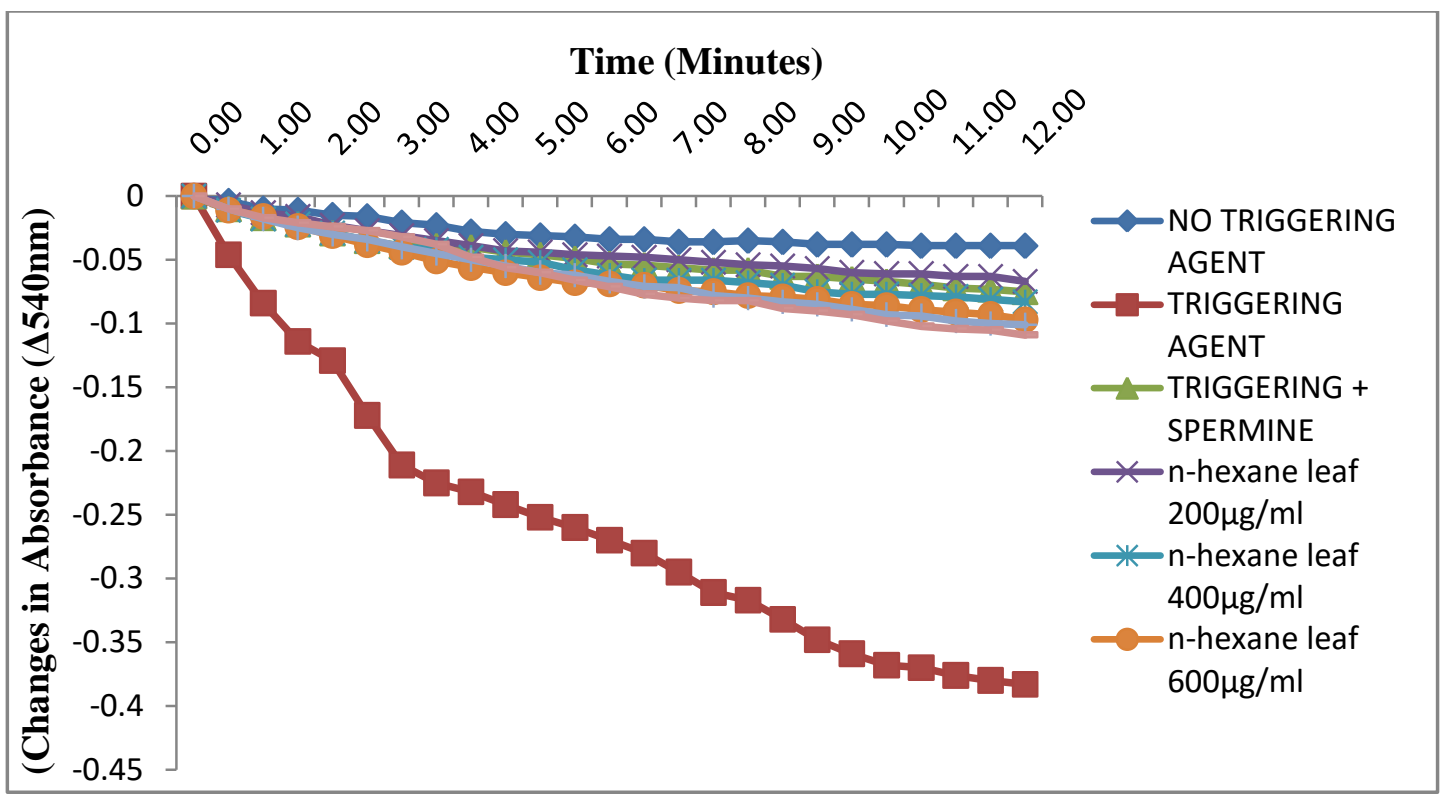

Figure 4: Showing the effect of Leaf n-Hexane Fraction (LHF) of Ficus exasperata at varied concentrations on mitochondrial Permeability Transition Pore.

As shown in Figure 4, all concentrations of Leaf n-Hexane Fraction of Ficus exasperata show significant $(P<0.05)$ induction. Such that a $\Delta_{540 \mathrm{~mm}}$ of -0.067 (1.72-fold increase) was observed at $200 \mu \mathrm{g} / \mathrm{ml}$. At $400 \mu \mathrm{g} / \mathrm{ml}, \Delta_{540 \mathrm{~mm}}=-0.083$ (2.13-fold increase). Also at $600 \mu \mathrm{g} / \mathrm{ml}, \Delta_{540 \mathrm{~nm}}=-0.097$ (2.50-fold increase). $\Delta_{540 \mathrm{~nm}}$ of -0.101 (2.59-fold increase) and $\Delta_{540 \mathrm{~mm}}$ of -0.109 (2.80-fold increase) were obtained respectively at $800 \mu \mathrm{g} / \mathrm{ml}$ and $1000 \mu \mathrm{g} / \mathrm{ml}$ of the fraction.

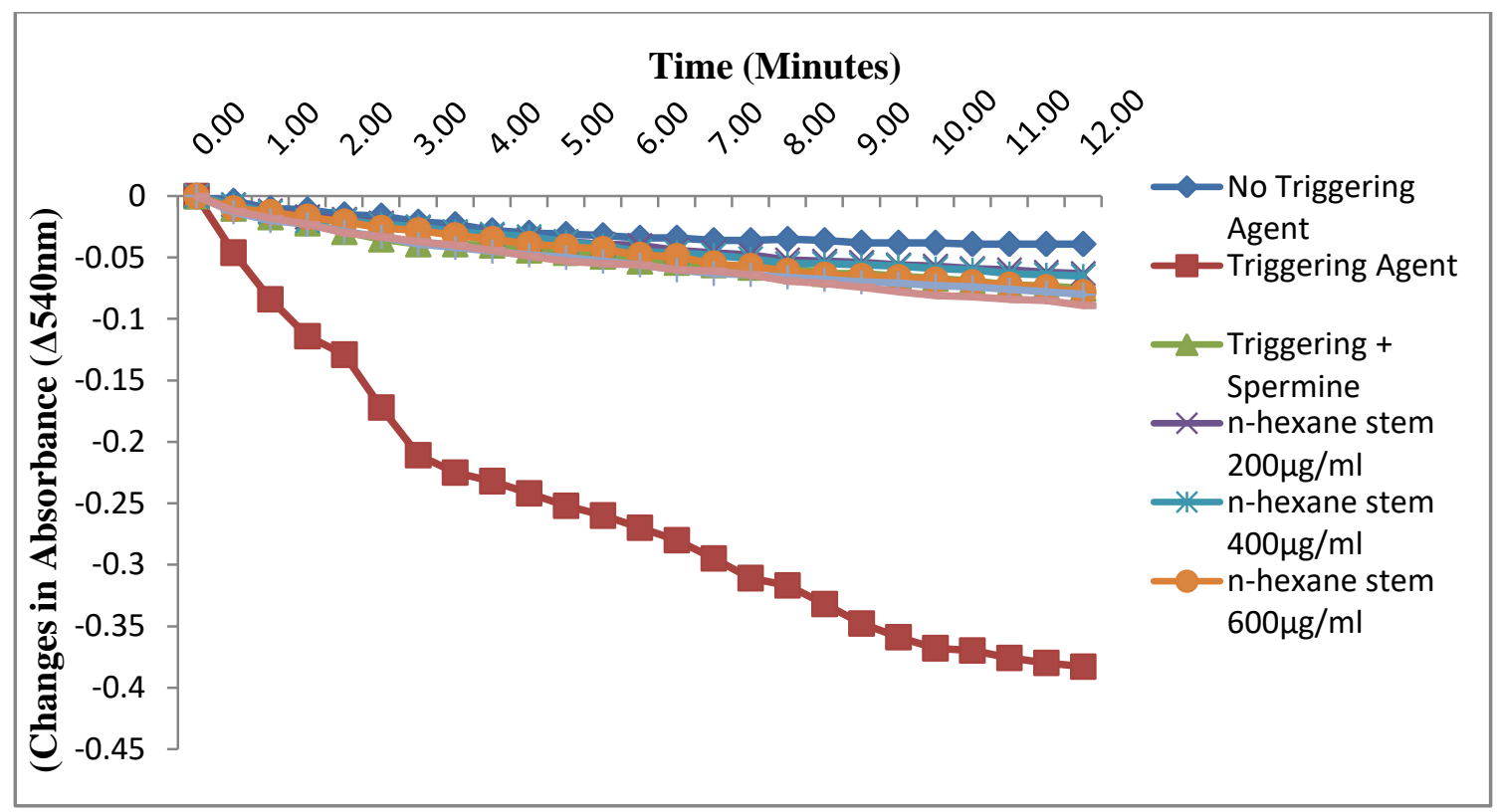

Figure 5: Showing the effect of Stem n-Hexane Fraction (SHF) of Ficus exasperata at varied concentrations on mitochondrial Permeability Transition Pore.

According to Figure 5, The SHF has a concentration dependent inductive effect in a pattern similar to LHF i.eat $200 \mu \mathrm{g} / \mathrm{ml}, \Delta_{540 \mathrm{~nm}}$ of -0.063 (1.62-fold increase); at $400 \mu \mathrm{g} / \mathrm{ml}, \Delta_{540 \mathrm{~nm}}=-0.065$ (1.67-fold increase); at $600 \mu \mathrm{g} / \mathrm{ml}$, $\Delta_{540 \mathrm{~nm}}=-0.078$ (2.0-fold increase); at $800 \mu \mathrm{g} / \mathrm{ml}$ and $1000 \mu \mathrm{g} / \mathrm{ml}, \Delta_{540 \mathrm{~nm}}$ of -0.080 (2.05-fold increase) and $\Delta_{540 \mathrm{~nm}}$ of - 
0.089 (2.28-fold increase) were obtained respectively. A significant induction of $P<0.05$ was observed at all concentrations.

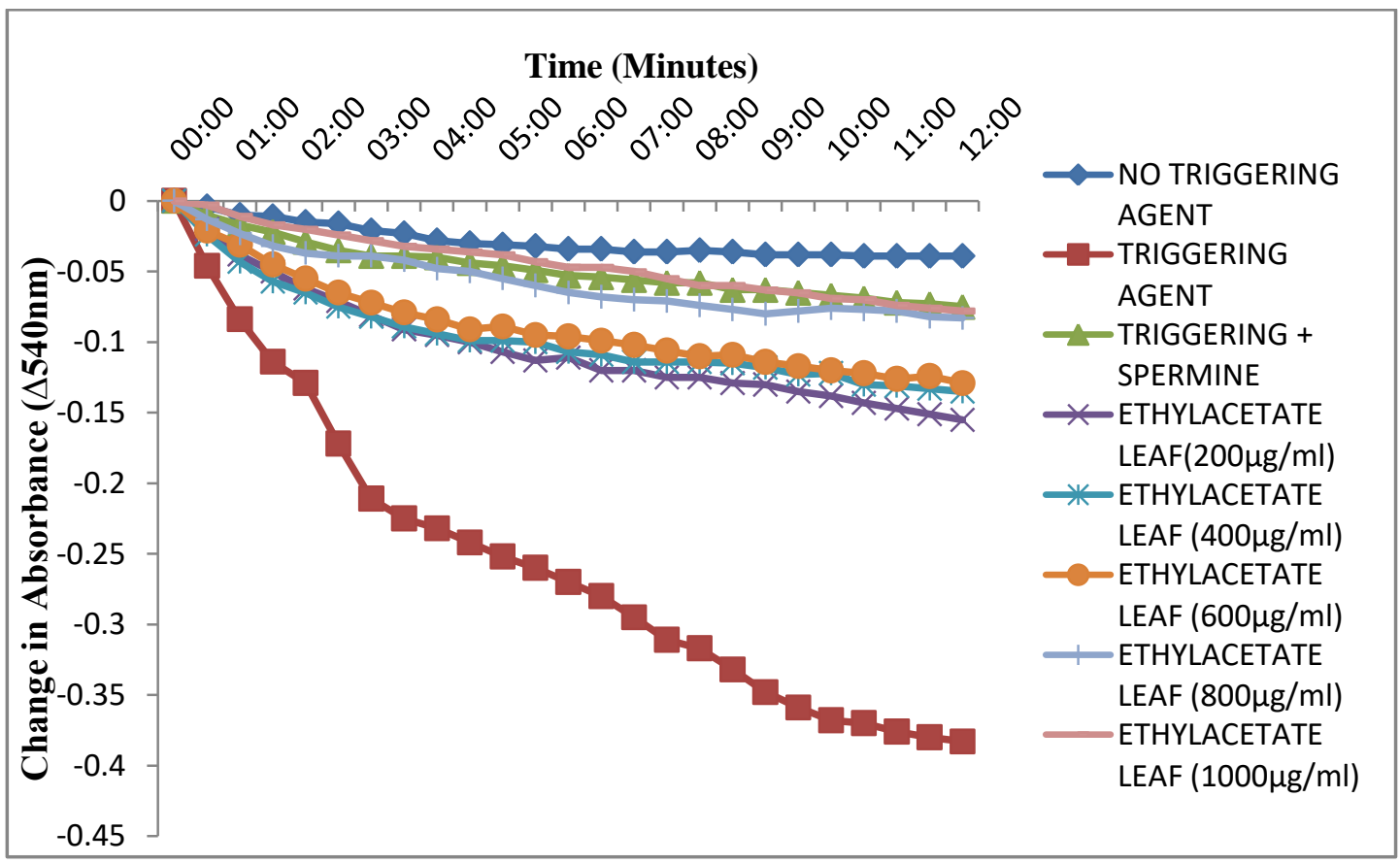

Figure 6: Showing the effect of Leaf Ethylacetate Fraction (LEF) of Ficus exasperata at varied concentrations on mitochondrial Permeability Transition Pore.

As represented in Figure 6, the inductive effects of leaf ethylacetate fraction of Ficus exasperata decreases as concentration increase and a significant induction took place at all concentrations. The result observed at varying concentrations is such that at $200 \mu \mathrm{g} / \mathrm{ml}$, a $\Delta_{540 \mathrm{~nm}}=-0.155$ (3.97-fold increase), at $400 \mu \mathrm{g} / \mathrm{ml}, \Delta_{540 \mathrm{~nm}}=-0.078$ which translates to -0.135-fold increase, at $600 \mu \mathrm{g} / \mathrm{ml}, 800 \mu \mathrm{g} / \mathrm{ml}$ and $1000 \mu \mathrm{g} / \mathrm{ml}, \Delta_{540 \mathrm{~mm}}$ of -0.129 (3.30-fold increase), $\Delta_{540 n m}$ of -0.083 (2.12-fold increase) and $\Delta_{540 \mathrm{~nm}}$ of -0.078 (2.0-fold increase) were obtained respectively.

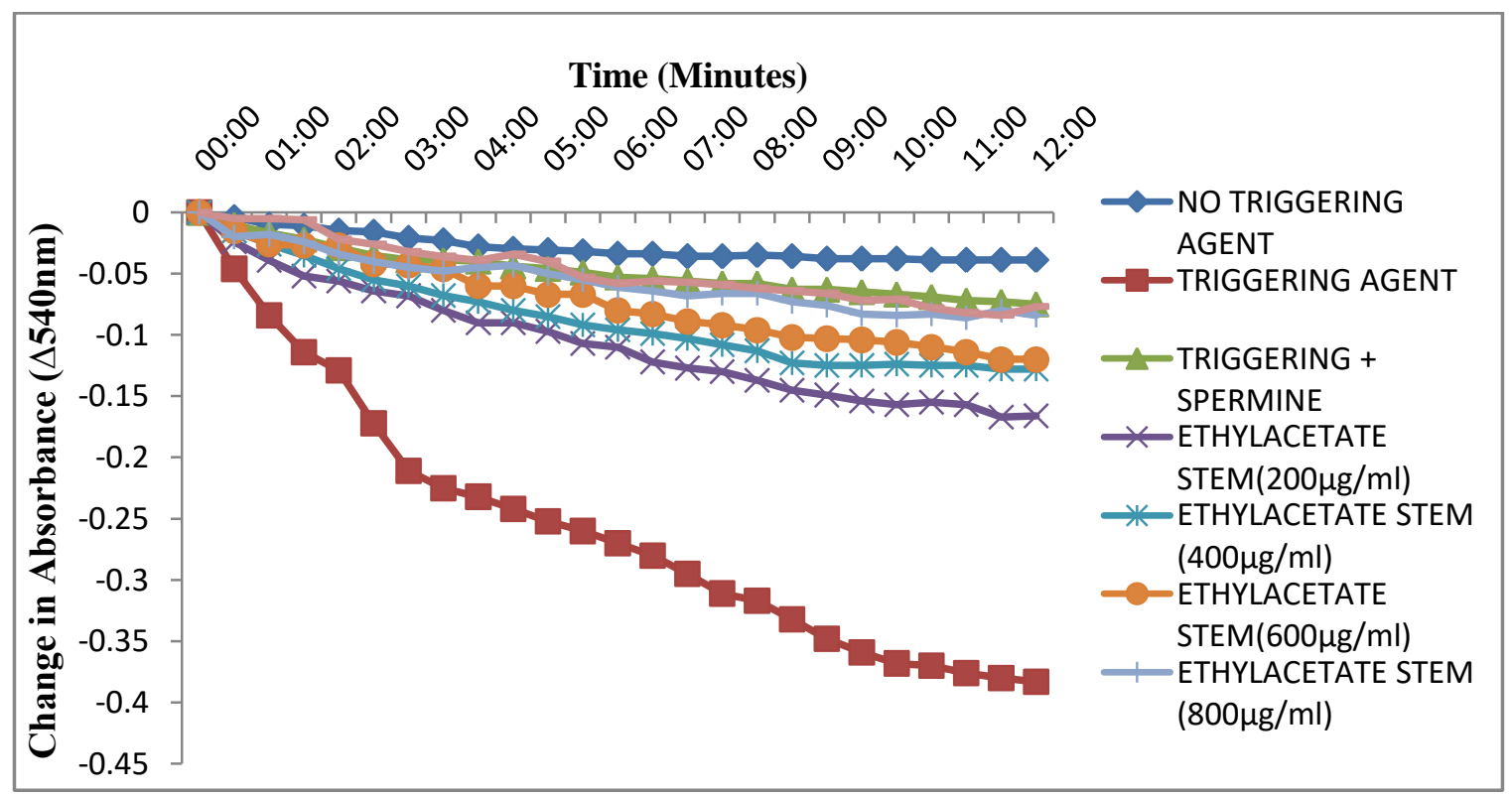

Figure 7: Showing the effect of Stem Methanol Fraction (SMF) of Ficus exasperata at varied concentrations on mitochondrial Permeability Transition Pore. 
Figure 7 shows that the inductive effect of Stem ethylacetate fraction of Ficus exasperata decreases as concentration increase such that at $200 \mu \mathrm{g} / \mathrm{ml}, 400 \mu \mathrm{g} / \mathrm{ml}, 600 \mu \mathrm{g} / \mathrm{ml}, 800 \mu \mathrm{g} / \mathrm{mland} 1000 \mu \mathrm{g} / \mathrm{ml}, \Delta_{540 \mathrm{~mm}}=-0.166$ (4.25-fold increase), - 0.128 (3.28-fold increase), - 0.120 (3.07 fold-increase), -0.084 (2.15-fold increase), and-0.077 (1.97-fold increase) respectively.

TABLE 1: Summary of the inductive effect of Leaf Methanol Fraction (LMF) and Stem Methanol Fraction (SMF) on MMPT pore in Wistar male rat.

\begin{tabular}{|c|c|c|}
\hline GROUP $(n=4)$ & $\begin{array}{l}\text { FOLD } \\
\text { INCREASES }\end{array}$ & $\begin{array}{l}\text { CHANGES IN } \\
\text { ABSORBANCE }\left(\Delta_{540 \mathrm{~nm}}\right)\end{array}$ \\
\hline NO TRIGGERING & 1.00 & $-0.039 \pm 0.001472$ \\
\hline $200 \mu \mathrm{g} / \mathrm{ml} \mathrm{LMF}$ & 2.94 & $-0.115 \pm 0.002041$ \\
\hline $400 \mu \mathrm{g} / \mathrm{ml} \mathrm{LMF}$ & 3.17 & $-0.124 \pm 0.001633$ \\
\hline $600 \mu \mathrm{g} / \mathrm{ml} \mathrm{LMF}$ & 2.41 & $-0.094 \pm 0.001414$ \\
\hline $800 \mu \mathrm{g} / \mathrm{ml} \mathrm{LMF}$ & 1.61 & $-0.063 \pm 0.001225$ \\
\hline $1000 \mu \mathrm{g} / \mathrm{ml} \mathrm{LMF}$ & 1.51 & $-0.059 \pm 0.001472$ \\
\hline $200 \mu \mathrm{g} / \mathrm{ml} \mathrm{SMF}$ & 2.84 & $-0.111 \pm 0.004143$ \\
\hline $400 \mu \mathrm{g} / \mathrm{ml} \mathrm{SMF}$ & 3.17 & $-0.124 \pm 0.00075$ \\
\hline $600 \mu \mathrm{g} / \mathrm{ml} \mathrm{SMF}$ & 2.89 & $-0.113 \pm 0.004601$ \\
\hline $800 \mu \mathrm{g} / \mathrm{ml} \mathrm{SMF}$ & 2.58 & $-0.101 \pm 0.001080$ \\
\hline $1000 \mu \mathrm{g} / \mathrm{ml}$ SMF & 2.51 & $-0.098 \pm 0.001041$ \\
\hline Triggering agent & 9.82 & $-0.383 \pm 0.001080$ \\
\hline
\end{tabular}


TABLE 2: Summary of the inductive effect of Leaf n-Hexane Fraction (LHF) and Stem n-Hexane Fraction (SHF) on MMPT pore in Wistar male rat.

\begin{tabular}{|c|c|c|}
\hline $\begin{array}{l}\text { GROUP } \\
(n=4)\end{array}$ & $\begin{array}{l}\text { FOLD } \\
\text { INCREASES }\end{array}$ & $\begin{array}{ll}\text { CHANGES } & \text { IN } \\
\text { ABSORBANCE }\left(\Delta_{540 \mathrm{~nm}}\right) & \end{array}$ \\
\hline NO TRIGGERING & 1.00 & $-0.039 \pm 0.001472$ \\
\hline $200 \mu \mathrm{g} / \mathrm{ml} \mathrm{LHF}$ & 1.62 & $-0.063 \pm 0.0008332$ \\
\hline $400 \mu \mathrm{g} / \mathrm{ml} \mathrm{LHF}$ & 1.67 & $-0.065 \pm 0.002056$ \\
\hline $600 \mu \mathrm{g} / \mathrm{ml} \mathrm{LHF}$ & 2.00 & $-0.078 \pm 0.001339$ \\
\hline $800 \mu \mathrm{g} / \mathrm{ml} \mathrm{LHF}$ & 2.05 & $-0.080 \pm 0.007360$ \\
\hline $1000 \mu \mathrm{g} / \mathrm{ml} \mathrm{LHF}$ & 2.28 & $-0.089 \pm 0.002483$ \\
\hline $200 \mu \mathrm{g} / \mathrm{ml} \mathrm{SHF}$ & 1.72 & $-0.067 \pm 0.001225$ \\
\hline $400 \mu \mathrm{g} / \mathrm{ml} \mathrm{SHF}$ & 2.13 & $-0.083 \pm 0.007070$ \\
\hline $600 \mu \mathrm{g} / \mathrm{ml} \mathrm{SHF}$ & 2.50 & $-0.097 \pm 0.001061$ \\
\hline $800 \mu \mathrm{g} / \mathrm{ml} \mathrm{SHF}$ & 2.59 & $-0.101 \pm 0.0004082$ \\
\hline $1000 \mu \mathrm{g} / \mathrm{ml} \mathrm{SHF}$ & 2.80 & $-0.109 \pm 0.001472$ \\
\hline Triggering agent & 9.82 & $-0.383 \pm 0.001080$ \\
\hline
\end{tabular}


TABLE 3: Summary of the inductive effect of Leaf Ethylacetate Fraction (LEF) and Stem Ethylacetate Fraction (SEF) on MMPT pore in Wistar male rat.

\begin{tabular}{|c|c|c|}
\hline $\begin{array}{l}\text { GROUPS } \\
(n=4)\end{array}$ & $\begin{array}{l}\text { FOLD } \\
\text { INCREASES }\end{array}$ & $\begin{array}{l}\text { CHANGES } \\
\text { ABSORBANCE }\left(\Delta_{540 \mathrm{~nm}}\right)\end{array}$ \\
\hline NO TRIGGERING & 1.00 & $-0.039 \pm 0.001472$ \\
\hline $200 \mu \mathrm{g} / \mathrm{ml} \mathrm{LEF}$ & 3.97 & $-0.155 \pm 0.002041$ \\
\hline 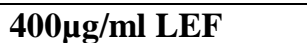 & 3.46 & $-0.135 \pm 0.002041$ \\
\hline $600 \mu \mathrm{g} / \mathrm{ml}$ LEF & 3.30 & $-0.129 \pm 0.001871$ \\
\hline $800 \mu \mathrm{g} / \mathrm{ml}$ LEF & 2.12 & $-0.083 \pm 0.001080$ \\
\hline $1000 \mu \mathrm{g} / \mathrm{ml}$ LEF & 2.00 & $-0.078 \pm 0.002780$ \\
\hline $200 \mu \mathrm{g} / \mathrm{ml} \mathrm{SEF}$ & 4.25 & $-0.166 \pm 0.002160$ \\
\hline 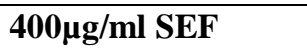 & 3.28 & $-0.128 \pm 0.001080$ \\
\hline $600 \mu \mathrm{g} / \mathrm{ml} \mathrm{SEF}$ & 3.07 & $-0.120 \pm 0.006455$ \\
\hline $800 \mu \mathrm{g} / \mathrm{ml}$ SEF & 2.15 & $-0.084 \pm 0.001633$ \\
\hline $1000 \mu \mathrm{g} / \mathrm{ml}$ SEF & 1.97 & $-0.077 \pm 0.002483$ \\
\hline Triggering agent & 9.82 & $-0.383 \pm 0.001080$ \\
\hline
\end{tabular}




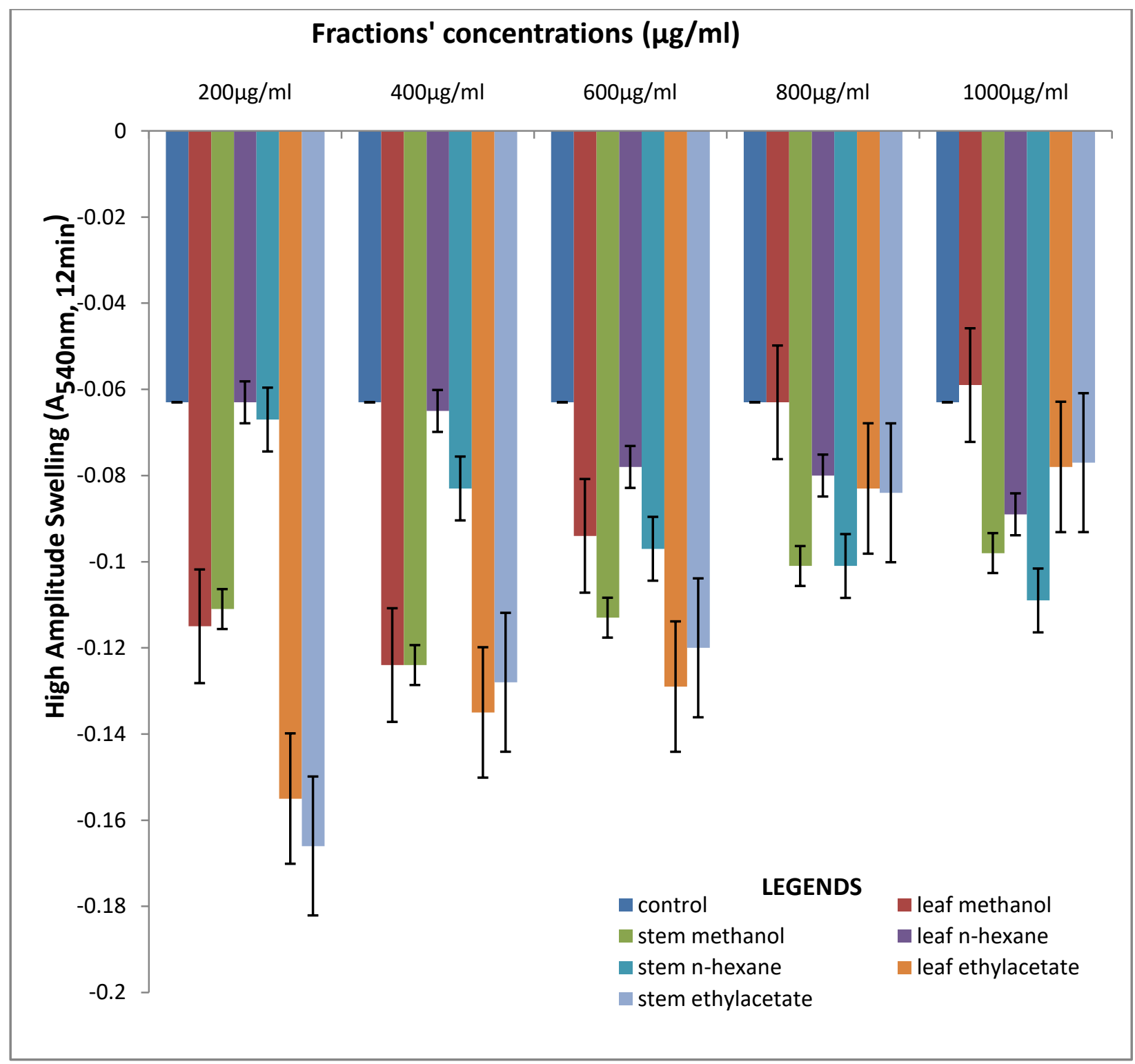

Figure 8: Comparison of the extents of induction of rat liver mitochondrial membrane permeability transition pore opening by Fractions of $F$. exasperata Bar charts shown are Means \pm S.E.M of data from four separate experiments using different mitochondrial preparations.

\section{DISCUSSION}

The mitochondrion has long been identified as a critical player in both the physiology and pathophysiology of a cell. The Mitochondrial Membrane Permeability Transition (MMPT) Pore is a popular phenomenon that has been implicated in Apoptosis. $\mathrm{Ca}^{2+}$ is a standard triggering agent capable of stimulating the opening of this pore. Certain plants have also been identified to possess phytochemicals that can trigger the opening of the MMPT pore ${ }^{\text {[38] }}$ culminating in apoptosis. Our current experiment has been able to authenticate the potency of phytochemicals in the leaf and stem of Ficus exasperata in the opening of the MMPT pore. F. exasperata induced MMPT pore opening of intact mitochondria suggesting that the presence of these phytochemicals is capable of altering the integrity of the affected mitochondrial membrane, albeit, the degrees and the patterns of induction varied for the different concentrations of the fractions that were assessed. The stem and leaf fractions of each solvent show similar pattern of induction. Among the six fractions, the SEF-treated group was the most potent as evidenced by its inductive 
effect on the pore up to about 4.25 -fold increase (at $200 \mu \mathrm{g} / \mathrm{ml}$ ) in comparison with the control group. The least inductive effect was observed at $1000 \mu \mathrm{g} / \mathrm{ml}$ of the LMF-treated group.

Arising from our gathered data; the pre-incubation of the leaf and stem of fractions of $F$. exasperata with mitochondria in the absence of $\mathrm{Ca}^{2+}$ induced large amplitude mitochondrial swellings, especially in the case of the SEF-treated group, we infer that the medicinal plant has bioactive agents capable of triggering apoptosis through a mitochondrial-mediated pathway. This inference is in tandem with the assertion of Chen and King, 2005 ${ }^{[38]}$ that the pathway of many dietary bioactive agents is via mitochondrial-mediated pathway having altered mitochondrial membrane function and/or dissipated the mitochondrial potential. Since MMPT pore may function as a selfamplifying "switch" that, once activated, irreversibly commits the cell to apoptosis, our finding suggests that the mode of induction of the pore by $F$. exasperata may not be unconnected to that known as the intrinsic apoptotic pathway in which induction of MMPT increases mitochondrial membrane permeability, causing mitochondria to become further depolarized and leading to the abolishment of membrane potential $(\Delta \psi)$. When $\Delta \psi$ is lost, protons

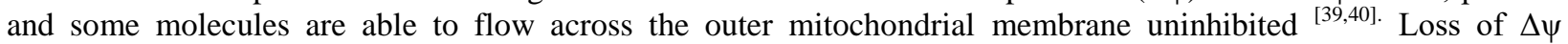
interferes with the production of adenosine triphosphate (ATP), the cell's main source of energy, (because mitochondria must have an electrochemical gradient to provide the driving force for ATP production) causing osmotic swelling and rupture of the outer membrane, with concomitant loss of mitochondrial proteins ${ }^{[41]}$ Owing to the critical role played by MMPT pore opening in apoptotic cell deaths much research has found that the fate of the cell after an insult depends on the extent of MPT. If MPT occurs to only a slight extent, the cell may recover, whereas if it occurs more it may undergo apoptosis. If it occurs to an even larger degree the cell is likely to undergo necrotic cell death ${ }^{[42]}$. Though, further work is needed to ascertain the actual mode of cell death induced by our choice plant, we here conclude that $F$. exasperata is a potent inducer of the mitochondrial membrane permeability transition pore; a critical actor in a cell's life-death balance. This thus suggests a potential use for $F$. exasperata in drug developments for ailments which will benefit from MMPT pore induction.

\section{CONCLUSION}

This work suggests that the pre-incubation of fractions derived from Leaf and Stem of Ficus exasperata to isolated mitochondria has an inductive effect on MMPT pore opening at different concentrations $(200-1000 \mu \mathrm{g} / \mathrm{ml})$. Although, they are less potent compared to $\mathrm{Ca}^{2+}$ in their ability to trigger the opening of the Mitochondria Membrane Permeability Transition Pore, the fractions clearly induced large amplitude swellings of the isolated mitochondria, an indication that the plants' phytochemicals may be of use in the management/treatment of pathological conditions such as cancer that may benefit from the killing (via apoptosis or necrosis) of the diseased cells.

\section{ACKNOWLEDGEMENT}

Prof. T. A. Adedosu and Mr. Debo Adeyeni of the Department of Pure and Applied Chemistry, Ladoke Akintola University of Technology, Ogbomoso are much appreciated for their assistance and guidance during the plant's extraction.

\section{FUNDING}

This research did not receive any specific grant from funding agencies in the public, commercial, or not-for-profit sectors.

\section{CONFLICT OF INTEREST}

Authors declare no conflict of interest.

\section{REFERENCES}

[1]. Schardt D. (2008). Manipulating mitochondria. Nutrition Action Health Letter, 35(10), 810.

[2]. Nicholls DG (1974a) Hamster brown adipose tissue mitochondria: the control of respiration and the proton electrochemical potential by possible physiological effectors of the proton conductance of the inner membrane. Eur. J. Biochem. 49, 573-583. 
[3]. Ling X, Zhou Y, Li S, Yan B and Wen L (2010) Modulation of mitochondrial membrane permeability transition pore affects multidrug resistance in human hepatocellular carcinoma cells. International Journal of Biological Sciences 6:773-783.

[4]. Bonora M, Wieckowski MR, Chinopoulos C, Kepp O, Kroemer G, Galluzzi L, Pinton P (2015). Molecular mechanisms of cell death: central implication of ATP synthase in mitochondrial permeability transition. Oncogene34: 1475 - 1486.

[5]. Bernardi, P., Broekemeier, K. M., and Pfeifer, D. R. (1994). Recent progress on regulation of the mitochondrial permeability transition pore; a cyclosporin-sensitive pore in the inner mitochondrial membrane. J. Bioenergetics and Biomembranes 26, 509-517.

[6]. Kroemer, G., Petit, P. X., Zamzami, N., Vayssiere, J.-L., and Mignotte, B. (1995). The biochemistry of programmed cell death. FASEB J. 9, 1277-1287.

[7]. Zoratti, M., and Szabo, I. (1994). Electrophysiology of the inner mitochondrial membrane. J. Bioenerg. Biomembr. 26, 543-553.

[8]. Zoratti, M., and Szabo, I. (1995). The mitochondrial permeability transition. Biochem Biophys.Acta 1241, 139176.

[9]. Liu J, Farmer JD, Jr., Lane WS, Friedman J, Weissman I, Schreiber SL (1991) Calcineurin is a common target of cyclophilin-cyclosporin A and FKBP- FK506 complexes. Cell 66:807-815.

[10]. Ling X, Zhou Y, Li S, Yan B and Wen L (2010) Modulation of mitochondrial membrane permeability transition pore affects multidrug resistance in human hepatocellular carcinoma cells. International Journal of Biological Sciences 6: 773-783.

[11]. Lockshin R and Zakeri Z (2004) Apoptosis, autophagy and more. International Journal of Biochemistry \& Cell Biology 36: 2405-2419.

[12]. Danial N and Korsmeyer S (2004) Cell death: critical control points. Cell 116: 205-219.

[13]. Reed J (2004) Apoptosis mechanisms: implications for cancer drug discovery. Oncology 18: 11-20.

[14]. Guimaraes C and Linden R (2004) Programmed cell death: apoptosis and alternative death styles. European Journal of Biochemistry 271: 1638-1650.

[15]. Sun S, Hail N and Lotan R (2004) Apoptosis as a novel target for cancer chemoprevention. Journal of the National Cancer Institute 96: 662-672.

[16]. Ijeh II, Ukweni AI (2007). Acute effect of administration of ethanol extracts of Ficus exasperate vahl on kidney function in albino wistar rats. J. Med. Plant Res. 1(2):027-029.

[17]. E. A. Adebayo, O. R. Ishola, O. S. Taiwo, O. N. Majolagbe and B. T. Adekeye (2009). Evaluations of the methanol extract of Ficus exasperata stem bark, leaf and root for phytochemical analysis and antimicrobial activities; African Journal of Plant Science Vol. 3 (12), pp. 283-287.

[18]. Berg CC, Wiebes JT. (1992) African fig trees and fig wasps. $1^{\text {st }}$ ed. Amsterdam: Koninklijke Nedrlandse Akademie van Wetens chappen.

[19]. GRIN. Germplasm Resources Information Network. [Online Database]. USDA, ARS, National Genetic Resources Program. National Germplasm Resources Laboratory, Beltsville, Maryland; 1994. Available from:http:// www.ars-grin.gov/npgs/. [Last accessed on 2013 Jan 31].

[20]. Berg CC. Moraceae. In: Flora Zambesiaca.Vol. 9, Part 6. London: Crown Agents for Oversea Governments and Administrations; 1991.

[21]. Akah PA, Orisakwe OE, Gamaniel KS, Shittu A, (1998). Evaluation of Nigerian traditional medicines: II. effects of some Nigerian folk remedies on peptic ulcer. J Ethnopharmacol ;62:123-700.

[22]. Ayinde BA, Omogbai EK, Amaechina FC (2007). Pharmacognosy and hypotensive evaluation of Ficus exasperataVahl (moraceae) Leaf. Acta Pol Pharm;64:543-6.

[23]. Adewole SO, Adenowo T, Naicker T, Ojewole JA (2011). Hypoglycaemic and hypotensive effects of Ficus exasperataVahl.(Moraceae) leaf aqueous extract in rats.Afr J Tradit Complement Altern Med;8:275-83.

[24]. Woode E, Poku RA, Abotsi WK (2011). Anxiolytic-like effects of a leaf extract of FicusexasperataVahl (Moraceae) in Mice. West Afr J Pharm ;22:75-81.

[25]. Woode E, Poku RA, Ainooson GK, Boakye-Gyasi E, Abotsi WK, Mensah TL (2009). An Evaluation of the antiinflammatory, antipyretic and antinociceptive effects of Ficusexasperata (Vahl) leaf extract. J PharmacolToxicol ;4:138-51.

[26]. Bafor EE, Omogbai EK, Ozolua RI (2011). Oxytocin inhibiting effect of the aqueous leaf extract of Ficus exasperata(Moraceae) on the isolated rat uterus. Acta Pol Pharm;68:541-7.

[27]. Odunbaku OA, Ilusanya OA, Akasoro KS (2008). Antibacterial activity of ethanolic leaf extract of Ficusexasperata on Escherichia coli and Staphylococcus albus. Sci Res Essay;3:562-4.

[28]. Ogunleye RF. (2011) Effectiveness of the leaf powder of Ficus exasperataVahl. (Moraceae) in suppressing the population of two major storage insect pests. Continental J Biol Sci;4:6-11.

[29]. Ayinde BA, Omogbai EK, Amaechina FC. Pharmacognosy and Ahmed, et al.: Phytopharmacology of Ficus exasperatahypotensive evaluation of Ficus exasperata Vahl (moraceae) Leaf. Acta Pol Pharm 2007;64:543-6.

[30]. Adebayo EA, Ishola OR, Taiwo OS, Majolagbe ON, Adekeye BT. Evaluations of the methanol extract of Ficus exasperata stem bark, leaf and root for phytochemical analysis and antimicrobial activities. Afr J Plant Sci 2009;3:283-7. 
[31]. Ogunleye DS, Adeyemi AA, Sanni AM. Hypoglycemic activities of the stem bark of Cola acuminate Vahl and leaf of Ficus exasperata(P. Beauv) Schott and Endl. Nig Ot J Hosp Med 2003;13:58-60.

[32]. Dongfack MD, Wandji J, Lallemand MC, Tillequin F. New acyl-glucosylsterol with unusual fatty acids from Ficus exasperata. Natural products with pharmaceutical, nutraceutical, cosmetic and agrochemical interest. $7^{\text {th }}$ joint meeting of AFERP, ASP, GA, PSE and SIF. Athens, Greece: 2008.

[33]. Johnson, D., and Lardy, H., 1967. Isolation of Liver and Kidney mitochondria. Methods in Enzymol. 10 : 94 96

[34]. Lapidus RG and Sokolove PM (1993) Spermine inhibition of the permeability transition of isolated rat liver mitochondria: An investigation of mechanism. Journal of Biochemical and Biophysical Methods 64: 246-253.

[35]. Ehigie A.F, Ehigie L.O, Odediran S.A, Adedosu O.T, Afolabi K. O. and Olorunsogo O.O. (2013) In vitro induction of rat liver mitochondrial Membrane Permeability transition pore opening by solvent extracts of Momordica charantia leaves. Biokemistri, Vol. 25 (2) 52-60.

[36]. Lowry, O. H., Rosebrough, N. J., Farr, A. I., and Randall, R. J., 1951. Protein Measurements with the Folinphenol reagent. J. Biol. Chem.

a. $193,260-265$

[37]. Lemasters, J. J., Theruvath, T. P., Zhong, Z., \& Nieminen, A. L. (2009). Mitochondrial calcium and the permeability transition in cell death. Biochimica et biophysica acta, 1787(11), 1395-401.

[38]. Chen, C. and King, A. (2005). "Dietary cancer-chemopreventive compounds: from signaling and gene expression to pharmacological". Trends in Molecular Medicine, 26: 318-328.

[39]. Schinder, A. F.; Olson, E. C.; Spitzer, N. C.; Montal, M. (1996). "Mitochondrial dysfunction is a primary event in glutamate neurotoxicity". The Journal of Neuroscience. 16 (19): 6125-6133.

[40]. White, R. J.; Reynolds, I. J. (1996). "Mitochondrial depolarization in glutamate-stimulated neurons: An early signal specific to excitotoxin exposure". The Journal of Neuroscience. 16(18): 5688-5697.

[41]. Liu X, Kim CN, Yang 1, Jemmerson R, Wang X (1996) Induction of apoptotic program in cell-free extracts: requirement for dATP and cytochrome c. Cell 86:147-157

[42]. Honda H.M., Ping P. (2006). "Mitochondrial Permeability Transition in Cardiac Cell Injury and Death". Cardiovascular Drugs and Therapy. 20 (6): 425-432. 